\title{
Active structural evolution of the western and central parts of the Pannonian basin: a geomorphological approach
}

\author{
F. Síkhegyi \\ Geological Institute of Hungary, H-1443 Budapest, Stefánia út 14., Hungary (Email: sikhegyi@ mafi.hu)
}

Received: 2 May 2000 - Accepted: 12 June 2001

\begin{abstract}
The recent tectonics of the western and central parts of the Pannonian basin has been investigated using morphological, geomorphological and hydrographical analysis of the present day topography. Analyses show that the whole North Pannonian unit (NPU) and Mecsek-Villány Range (from the Tisza unit) moves to ENE direction with a gentle counterclockwise rotation. Final conclusions of the investigations suggest that lateral extrusion of the Eastern Alps is still the main, determining factor in the forming of surface morphology and in distribution of the genetic types of the Quaternary deposits.
\end{abstract}

\section{Introduction}

Tectonic movements on the Earth's surface are accompanied by both vertical and horizontal crustal movements. The vertical component of tectonic motion tends to result either in erosion of uplifting areas or deposition in subsiding areas. Consequently, denudation and sedimentation become spatially separated in the continents. Thickness distribution of Quaternary deposits, geomorphological processes and genetic types of recent sediments therefore reflect the general trends of vertical crustal movements. A separation of sedimentary regimes occurs even if only the relative movement of the neighbouring areas is opposite. Therefore, this method cannot determine the absolute direction of tectonic movements, only shifts of specific blocks relative to one another.

Prior to the recognition of plate tectonics, recent tectonic movements were explained first of all by vertical movements induced by isostatic effects and, to a lesser extent, by lateral forces. Plate tectonics resulted in attributing a much greater role to lateral movements and regarding the vertical ones as the effects of lateral events. Identification of lateral displacements in Quaternary terrestrial formations is difficult using traditional mapping methods. Lateral displacements can only be verified for example by identifying vertical bedding planes, fold axes, and movements along faults, or by peculiarly different sequences in drilling profiles on oppo- site sides of faults that cannot be attributed to lateral facies changes. At the same time, recent lateral movements may be accompanied by the formation of characteristic geomorphological patterns, such as anomalies in drainage network and characteristic sediments (Sabins, 1978; Brown and Kockelman, 1983).

Extension or compression in association with lateral movements initiate highs and depressions along fault zones (positive and negative flower structures). The vertical shift of the surface above the bulging or slumping sediments, depending on the penetrated depth, is usually greater than the inducing lateral shift. The accompanying vertical movements magnify thus the effects of compression and extension in both the changing surface morphology and the different character of associated Quaternary genetic types.

Geodetic measurement of vertical components of recent tectonic movements utilizes repeated, accurate levelling completed in time slices of several decades. Such measurements recorded uplift of the Carpathian arc, and subsidence of the lowest regions of the Pannonian basin including the Great and the Little Hungarian Plains and the northern Danube basin was observed (Joó et al., 1985; Joó, 1992). From its eastern and central part stable relative to Nadap, Transdanubia rises progressively towards the Alps. A levelling base network was defined for land survey purposes, thus it cannot be used to determine more detailed differential tectonic movements.

There is a contradiction between the $0.2 \mathrm{~mm} /$ year subsidence velocity based on the thickness of basin sediments (Rónai, 1986) and the maxima of recent subsidence measurements exceeding $6 \mathrm{~mm} / \mathrm{year}$. The explanation may lie in oscillations in movements and related sedimentation rates. Compaction of the Tertiary sedimentary fill, as well as groundwater pumping can also contribute to these anomalies. The latter is confirmed by the maximum subsidence values located under the large cities of the Great Hungarian Plain.

A prerequisite for making effective morpho-structural analysis is the presence of tectonically deformed topography 


\section{UPLIFT}

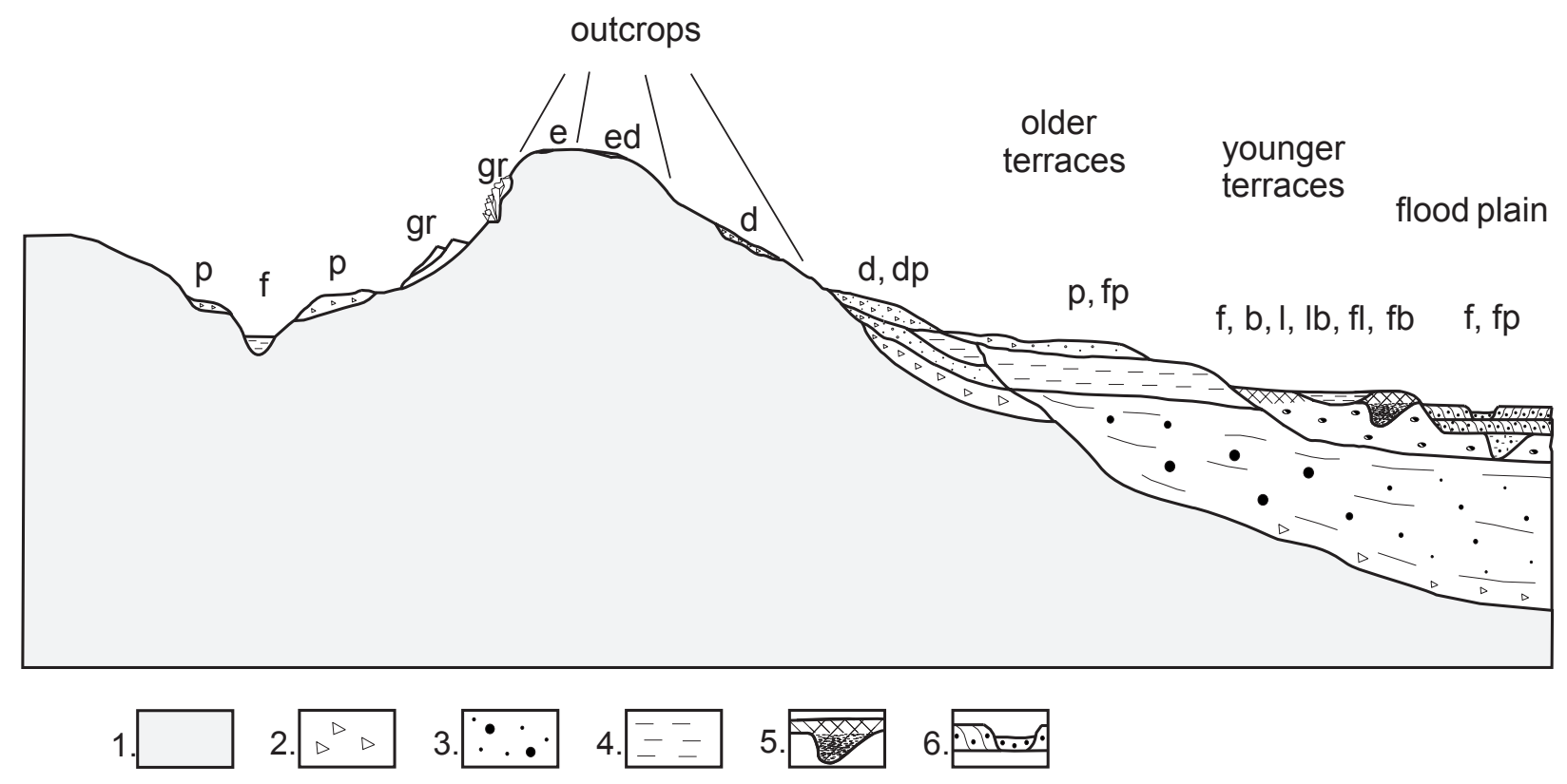

Fig. 1. Occurrences of the Quaternary genetic types in the uplift and subsidence areas (Síkhegyi, 1995.) Keys: 1: Bedrocks, 2: Angular, poorly rounded, poorly sorted sediments, 3: Well rounded, sorted fluvilal beds, 4: Fine-grained sediments, 5: Buried river channels, 6: Point bars. Abbreviations of genetic types: f: fluvial; p: proluvial; e: eluvial; d: deluvial; gr: gravitational; 1: lacustrine; b: paludal (bogs) — and their different combinations.

and precisely dated, young sediments. In this respect, the central and western parts of the Pannonian basin are considerably more suitable for such studies than its eastern areas, due to the widespread occurrence of Pannonian and younger sediments in Transdanubia and nearby regions. At the same time, extensive Upper Pleistocene and Holocene fluvial complexes cover the central part of the basin, i.e. the Great Hungarian Plain. These fluvial sediments form thick alluvial plains and associated alluvial fans. Rapid fluvial sedimentation can cover, erode or rework the underlying formations, which eliminate the structures identifiable in morphology. Therefore the regions east of the Tisza and Drava rivers were omitted from this study.

Displacements revealed by the distribution and morphology of Quaternary formations are the results of processes acting occasionally through several hundreds of thousand years. Some seismically active features cannot thus be identified on the basis of morphological patterns. This applies to the Komárom (K.) - Mór (M.) - Berhida (Bh.) zone. For identification of geographical units and abbreviations, see Fig. 10.

\section{Methods}

Our previous work (Síkhegyi et al., 1996) was used as the starting point for this analysis. This previous study separated genetic types of Quaternary sediments for the whole territory of Hungary. The related theoretical profile is presented in Fig. 1. We suggested that substantial vertical displacements occurred during the Quaternary along faults that form the surface boundaries between areas of accumulation and sedimentation. This contact arrangement can be related to the faults penetrating the youngest formations, but also to the filling of pre-existing, tectonically preformed troughs or valleys manifested in the late Quaternary morphology.

Figure 2 shows a part of the most important map used for analysis. The map presenting the sinking areas was compiled using the 1:200 000 geological map series. Additionally, other maps available for some fragments of the whole area were also taken into account, such as the map of superficial mass movements and the most recent neotectonic maps (Maglay et al., 1999; Halouzka et al., 1998).

Analysis of materials associated with aerial and remote sensing imageries, including available satellite images, also contributed to the evaluations. Radar images of the ERS- 1 satellite serves as a basis for morphological studies and geomorphological classification. Visual interpretation of Landsat TM false colour composites were also used for the evaluation.

The Geological Institute of Hungary (MÁFI) has recently obtained the digital terrain model (DTM-10 delivered from contour lines of 50000 scale military topography with a 10 by $10 \mathrm{~m}$ grid size) and topographic base (DTA-50) of the whole country and some neighbouring regions. Figure 3 presents the coloured digital relief map of the western Pannonian basin deduced from DTM-10. 

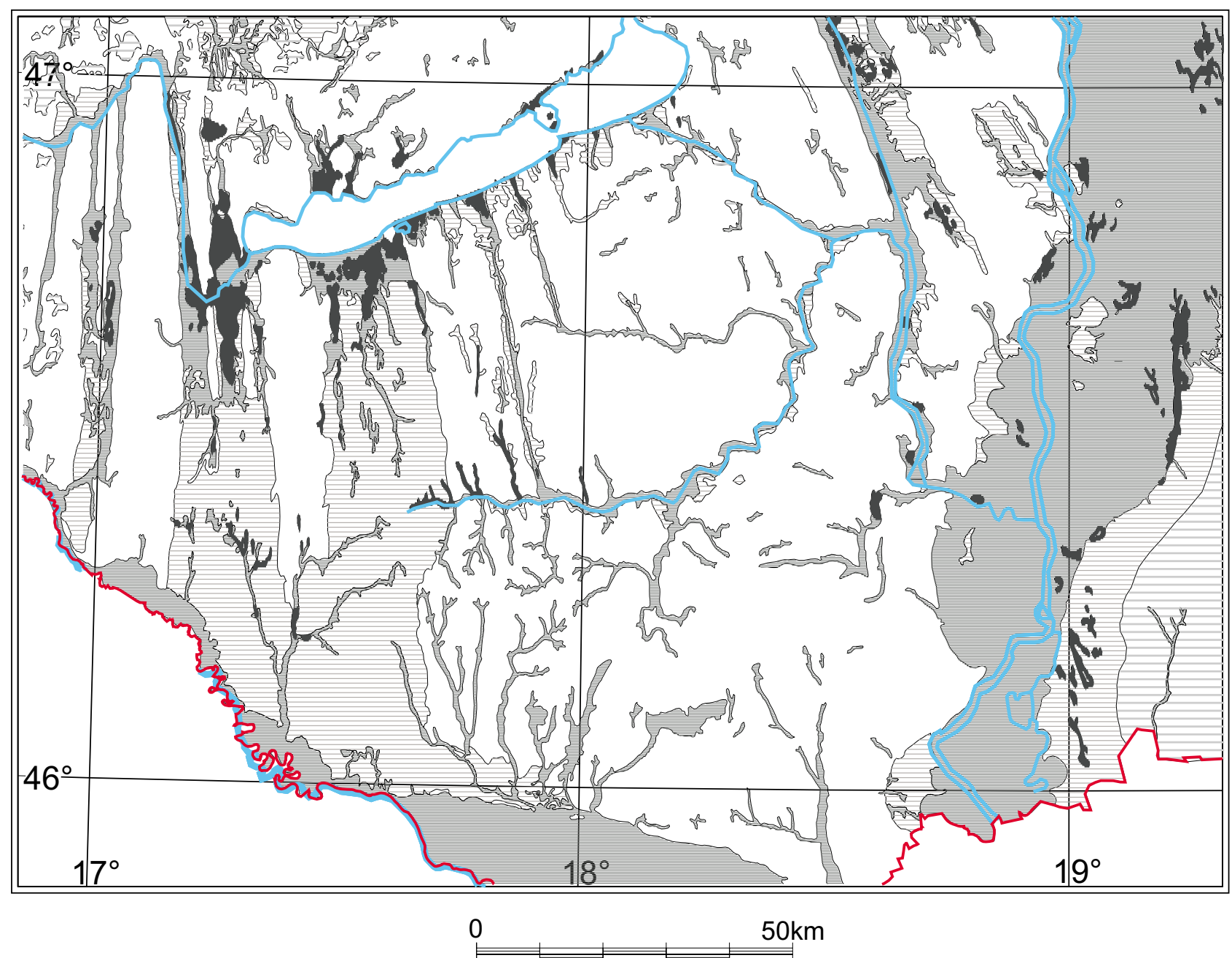

1.

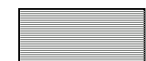

2.

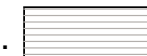

3.

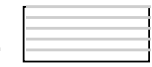

4.

Fig. 2. Main depositional types in southern Transdanubia during the Pleistocene and Holocene times (Síkhegyi et al., 1992). 1: Recent flood plain deposits, 2: Holocene to Middle Pleistocene river terrace sediments, 3: Middle and Early Pleistocene deposits of rivers and alluvial fans, 4: Holocene lacustrine and paludal deposits.

\section{Summary of former neotectonic studies in the investi- gated area}

\subsection{Typical geological formations}

Structurally, the investigated part of the Pannonian basin is surrounded by the Western Carpathians, the eastern termination of the Alps and the Neogene and older formations of the Dinarides. Among the Quaternary sediments of these ranges, typical genetic types of post-uplift sedimentation prevail. From the E-SE, the study area is surrounded by the depression of the central part of the Pannonian basin filled with Upper Miocene (Pannonian) to Quaternary sediments of several thousand meters thickness, as well as alluvial fans protruding from piedmont regions.
Extensive Pannonian formations, proluvial and alluvial fans of different Pleistocene rivers, eolian sands and loesses were deposited on the surface of Transdanubia and in its surroundings. The youngest and deepest basins of these regions filled with fluvial sediments are the Little Hungarian Plain (LHP) - Csallóköz (CSK) - Northern Danube basin (NDB) in the north, and the Drava- (DV) and Mura (MV) valleys encircling Papuk Hill (PPH) in the south. The region in between is a lower hilly area with pre-Pannonian formations exposed on the surface of the eastern ranges of the Alps, the Hungarian Central Range (HCR) and the Mecsek - Villány Ranges (MR and VR). 


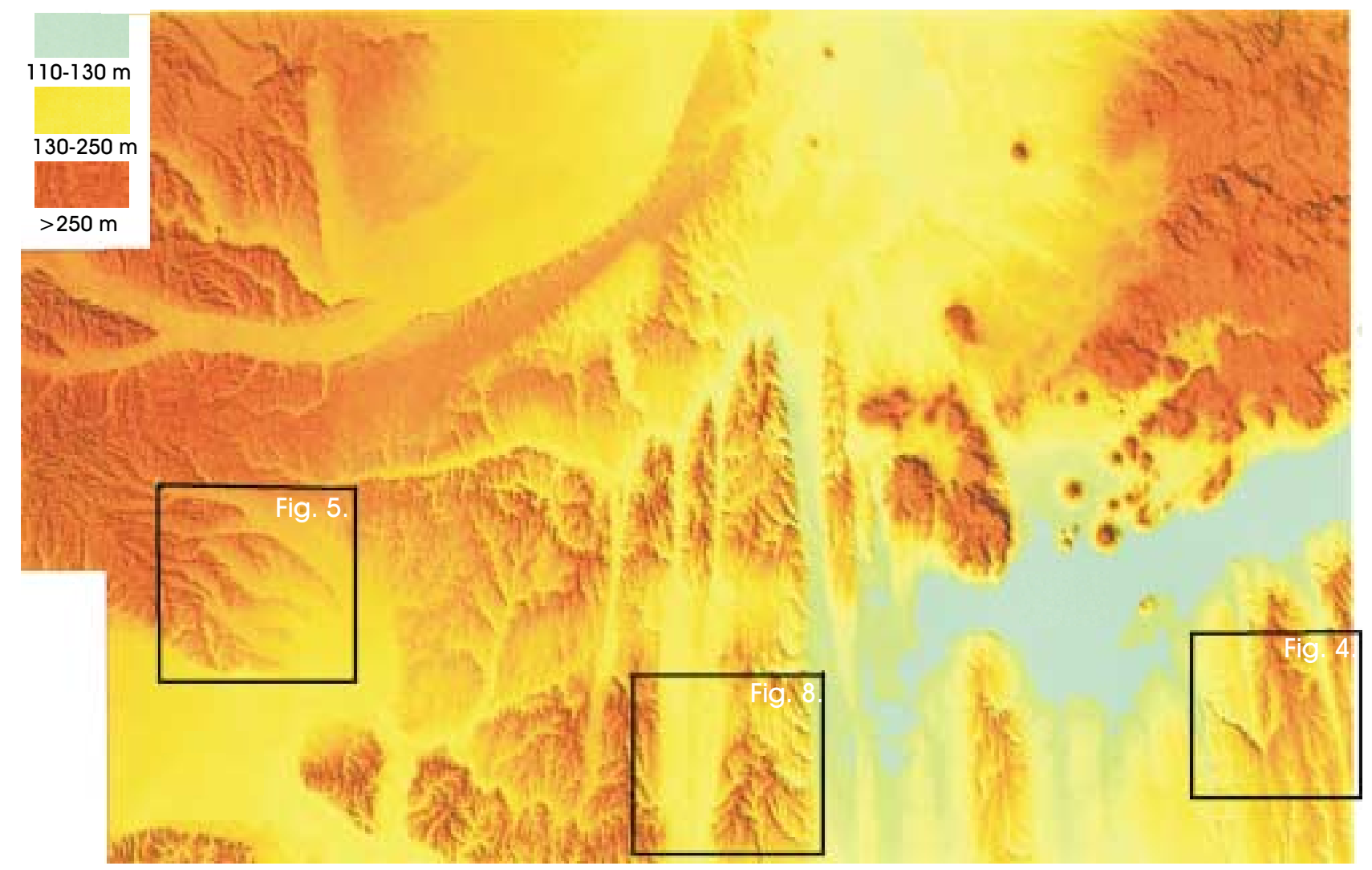

Fig. 3. Coloured hypsometric presentation of the DTM of West Hungary. Frames show the places of the detailed relief maps. Cartographic Office of the Hungarian Army.

\subsection{Neotectonic models}

The most distinct feature of the regions surrounded by alluvial plains is a characteristic radial pattern clearly manifested in morphology, hydrography and partly in the distribution of surface geological formations. To the west, in the Zala Hills $(\mathrm{ZH})$, this pattern has an N-W orientation, gradually becoming NW-SE directed, when approaching the central part of the Great Hungarian Plain. The interpretation of this pattern is a key problem. The question is not merely about the tectonic origin of this system, although this suggestion would imply intense neotectonic processes during the Pliocene and Quaternary periods. There are a number of theories concerning the origin of this peculiar morphostructural pattern. Gerner (1994) summarized these models for the southern part of Transdanubia, but the majority of his references can be applied to the Great Hungarian Plain as well.

$\mathrm{He}$ utilized three, not always clearly distinguishable groups of neotectonic models, namely (1) faulting, (2) folding and (3) imbricational structures.

There are also a number of counter-arguments brought up recently that deny tectonic processes during the Quaternary and explain the phenomena by stratigraphic features of the formations and the destructive effect of exogenic processes (slides, aeolian and aquatic erosion) (Balla et al., 1993; Marosi and Schweitzer, 1997; Balla, 1999).
The recognition and suggestion of a tectonic origin of the radial, complex structure typical for Transdanubia and the Danube-Tisza interfluve can be associated first of all with scientific surveys of Lake Balaton. Lóczy (1913) reporting on the tectonics of Pannonian - Pontian beds noted that based on morphological features south of Balaton he found similar embayments and valleys along the opposite shore of the lake Balaton, i.e. in the Bakony Range (BR) and the Balaton Highland $(\mathrm{BH})$. By his interpretation these amazingly straight $25-35 \mathrm{~km}$ long valleys extending all over Transdanubia from the Eastern Alps to the Great Hungarian Plain, follow normal and strike slip faults and trench depressions.

Cholnoky (1918) reported the same in more detail pointing out that these valleys do not have a distinct dip, fluvial terraces are missing, and the streams are underfit relative to the valleys through which they flow. Cholnoky also suggested that these valleys represent tectonic lines formed through repeated, parallel, shaking fault movements, subsequently enhanced by eolian deflation. The idea of tectonic preformation has reappeared in studies concerning the evolution of these valleys. The same idea was brought up by other authors (Lóczy, 1939; Körössy, 1963; Dank, 1979; Czakó, 1980) reporting on potential hydrocarbon occurrences.

The explanatory text of the 1:200000-scale geological map series of Hungary (Franyó et al., 1976) emphasised that younger, Quaternary movement phases have also a distinct 


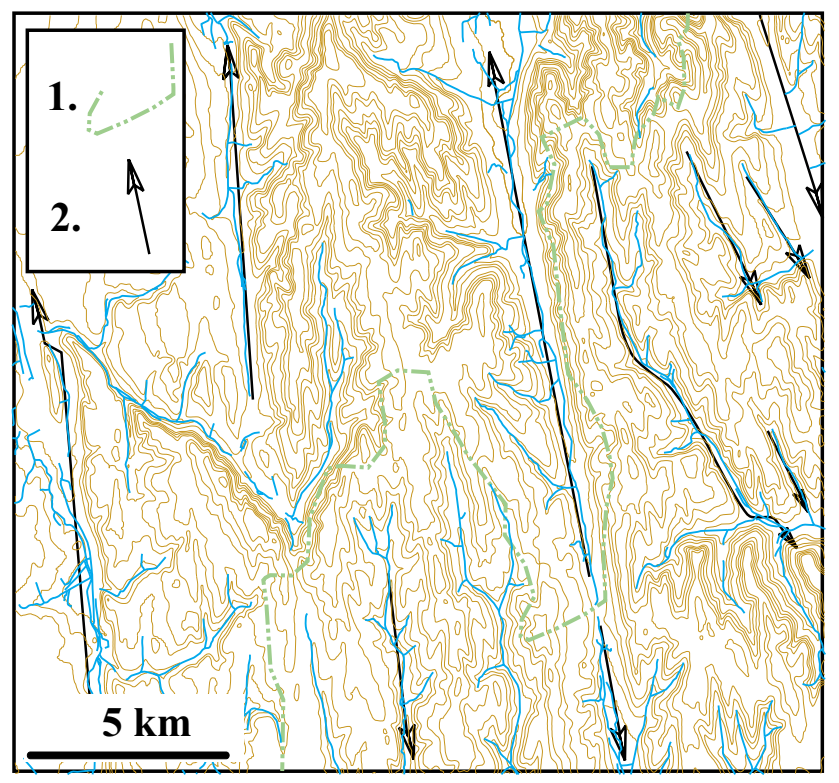

Fig. 4. Relief of the Külsô-Somogy (KS) area. 1: water shade, 2: direction of river flows.

impact on the morphology of Western Transdanubia. He suggested a tectonic origin for the graben of Lake Balaton and for the peat-bog depressions near Zalaszentmihály (Zszm). $\mathrm{He}$ assumed that they formed during the Riss-Würm interglacial period. Ádám et al. (1981) also suggested a tectonic origin for stream valleys in Southern Transdanubia. Moreover, they suggested that the current drainage pattern received its present configuration following the subsequent subsidence of the Kapos valley.

Pécsi (1986) summarised the ideas on the origin, focusing on the Zala valleys. Apart from the ideas of tectonic pre-formation and valley evolution through deflation, he also studied the theories suggesting fluvial erosion. He emphasised the counterarguments against it, stressing the lack of fluvial sediments comparable with the size of the valleys and missing river terraces. He also refers to the lack of evidence in the basement of Lake Balaton for rivers with a size like that of the presumed Proto-Danube that would have crossed the region.

Interpretation of space images visually evaluated by Rádai $(1978,1984)$ reinforced the tectonic origin hypotheses. The images allowed a comprehensive overview of the distinct radial structure and regular pattern of lineaments extending throughout the country. Czakó (1980) completed a statistical processing of the orientation of lineaments visually observable on satellite images of Mezóföld (MF). He concluded that NW-SE shear and almost perpendicular compression acted in the area after Pannonian (Late Miocene) sedimentation.

In recent times, Hungarian scientists have put forward two general evolution theories. Based on analogies of fan structures formed through extensional laboratory tests, Moldvay (1989) suggested a symmetrical, extensional, opening structure, uniform from the Czech-Moravian Hills up to Southern

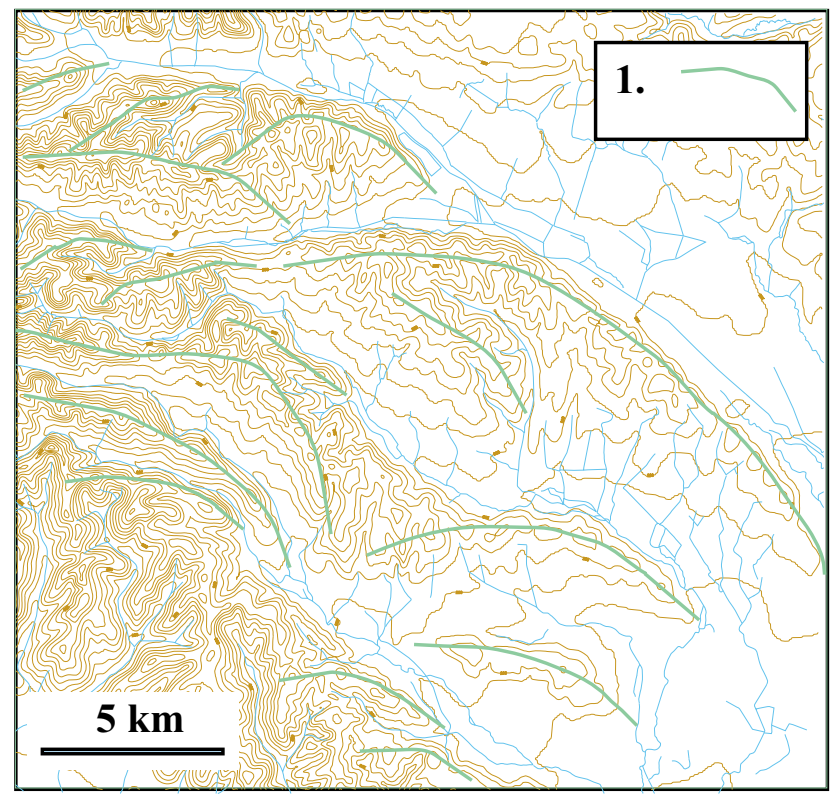

Fig. 5. Relief map of arched, truncated ridge- and valley system, west of Kerka valley (KV). 1: Ridge crests.

Transdanubia and Kiskunság (KK) formed by the opposite drift of the Alps and Carpathians. Gerner (1992) interpreted the radial fault structure as the sinistral antithetic fault system of a dextral strike slip fault zone extending along Lake Balaton. The change in their orientation is due to the changing nature of the stress field becoming compressional to transtensional from west to east.

A completely different idea from the above theories was brought up by Balla et al. (1993). As a result of tilting to the south, the drainage network and dry valleys are orientated along the dip line of the surface of bedding planes. There is no need in this case to suggest structural pre-formation, and the fan structure can be explained by the arched main faults of the basement, since dip lines of the tilted blocks are approximately perpendicular to them. The above hypothesis is naturally true for some specific geographical-geological units and the consequent valley system can directly be interpreted using remote sensing methods (Síkhegyi, 1985). The related block diagram applies throughout Somogy county up to Sárvíz valley (SV). At the same time, in some neighbouring land units where the drainage and valley network fits completely in the radial structure along the strikes, the orientation is just opposite. Here the erosion base level can be traced in the Lake Velence, Lake Balaton, Kis-Balaton (KB) and deep peat depressions without outlet located along strike of the lakes to the west (Zszm). In order to clarify relief characteristics, drainage and valley patterns and the stratigraphic setting of young sediments, as well as to investigate their relationship, it is necessary to study formations older than Pannonian, eventually together with faults reactivated after the Pannonian. 


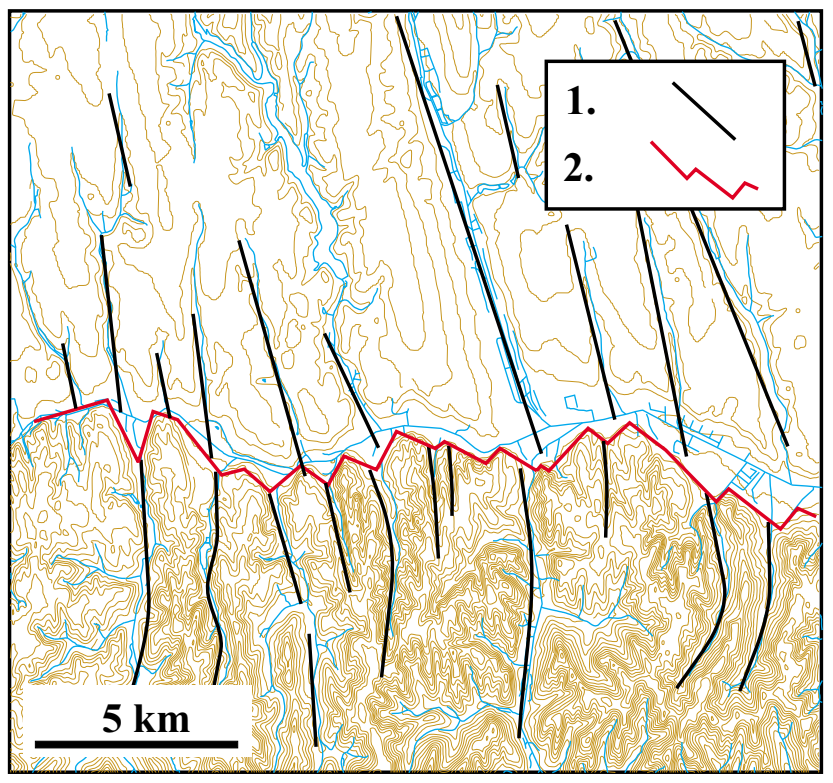

Fig. 6. Relief map of a part of the Kapos valley (KV). 1: Directions of the tributaries of the Kapos river, 2: Zigzagged headwall.

\section{Results of morphological investigations}

\subsection{Morphological features}

Concerning the drainage and closely associated valley network, we emphasise four characteristic and anomalous patterns emphasising their possible relationship to neotectonically controlled surface evolution:

- radial pattern of hydrography and valley network, tectonic control on the Danube river

- linear arrangement of drainage network reversings

- saw-tooth, zigzagged pattern of asymmetric valleys parallel to the main (ENE) structural direction of the Pannonian basement (R. Zala, R. Kapos, R. Koppány, R. Jaba, etc.)

- arched, asymmetric crest and valley pattern

- arched edges of the youngest and largest valleys (Danube, Drava R.).

Separation of the radial pattern of hydrography and valley network based on their orientation in Transdanubia and the northwestern part of the Great Hungarian Plain was presented in the explanatory text attached to the 1:500 000-scale lineament map of Hungary (Síkhegyi, 1992). According to the extent of the fan pattern, the main lines bordering major units is suggested between the Rába (RL) and Mecsekalja (MAL) lines and between the Szévíz valley (SZV) and the Cserhát - Mátra line (CSML).

The radial pattern is clearly manifested in the morphology (hydrography) and in the character of geological boundaries. Some morphostructural elements are of evidently tectonic origin. They include the morphologically distinct line

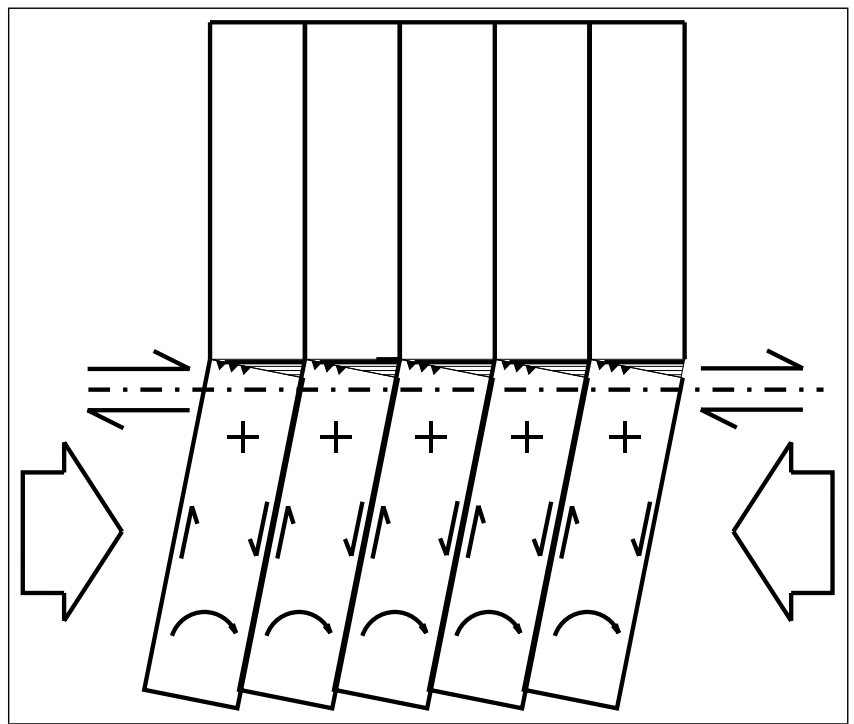

Fig. 7. Theoretical model of zigzagged morphological anomalies over shear zones.

of north-south direction, bordering the Transdanubian Range (TrR) to the west, the one bounding the Mecsek Range (MR) to the west and a line between Fonyód and Kaposvár, where the general drainage orientation switches. These faults are published in the study delineating zones of earthquake hazard in Hungary (Balla et al., 1993), as well as in the map of the boundaries of neotectonic blocks identified through the interpretation of lineaments on space images (Brezsnyánszky and Síkhegyi, 1987).

The topography and drainage network in the area south of Lake Balaton (Fig. 4) shows that the watershed parallel to the shore at a distance of $8-10 \mathrm{~km}$, westward gradually shifts parallel to the south along a single comb to a distance of $20-22 \mathrm{~km}$ from the lake. Further to the west, from the Kaposvár-Fonyód line it passes to the extension of the line of Kapos river some $40-50 \mathrm{~km}$ from the lake. The shifts take place always along valleys or combs coinciding with the radial pattern. Assuming that the valleys formed consequently, this picture can be explained by the presence of a parallel, fault system between Kaposvár (Kv.) and Fonyód (F.) along the Nagyárok (NAV), (Balla et. al., 1993).

According to the geological setting, the above specified regular, radial morphological pattern can be traced in the Mór trough (MT), the Váli-víz valley (VVV) and the Solymár trough (ST) (Fig. 10). The morphological boundary extending from the Danube bend towards Cegléd (C.) and several other, smaller morphological features of similar characteristics can be also attributed to the same pattern.

These small morphological features without any visible tectonic sign can be classified as tectonically crushed zones with or without small-scale displacements. These shear zones are subject to exogenous processes: pre-formed lines become visibly enhanced by incising rivers or streams or by the deposition of alluvial sediments. 
Tectonic control on the Danube rive by this pattern is a major factor along the course of the river between Gyôr (Gy.) and the southern border of Hungary. Its NW-SE orientated sections pass along pre-formed structural lines, while downstream their azimuths turn progressively southward in compliance with the orientation of the radial structures. There is no morphological evidence supporting the presence of young, N-S striking tectonic lines that would control the passage of the Danube from the northern edge of the Szentendre island (ISZ) down to its confluence with the Drava river.

The alternation of elongated, elevated ranges and valleys suggests extensional faultings. The youngest, overlying rocks can bury the original extent of the pattern: the Drava basin truncates the pattern from the SW without any trace. Moreover, the Moson-Danube basin NW from the Rába river and the southern part of the Kiskunság (KK) can be classified into these regions.

We saw that the systems and fractured structures passing through the Transdanubian Range, that is the Mór trough (MT), the Váli-víz valley (VVV) and the Solymár trough (ST), also fit in the radial pattern. Provided that it is not the consequence of an accidental coincidence, their formation cannot be restricted to a short time interval. Instead, they started to form still during Pannonian (Late Miocene) times. However they were active certainly mainly after Pannonian sedimentation dissecting the Upper Pannonian surface giving way to the Pliocene and Early Pleistocene terrestrial sedimentation (Pécsi, 1986.).

It is also uncertain to date the end of this tectonic process. The straight morphological and geological borders between the Upper Pleistocene loesses and aeolian sands are also parts of the same pattern. Consequently, vertical displacements along the lines of this morphological pattern have pre-formed the morphology for the aeolian sedimentation, thus they formed during Early to Middle Pleistocene times.

The spatial arrangement of the eastern margin of the alluvial fans in the Zala Hills and the western border of loesses plateaus is also peculiar as observed along the straight line of the Szévíz valley (SZV). It is by no means typical for aeolian sediments, nor for alluvial fans in their original shape. Consequently, surface extension and deflation were still active along some lines even after the development of alluvial fans and may have lasted until the formation of Upper Pleistocene loesses.

The youngest, recent extension associated with the radial pattern can be identified in the Solt Plain (SP) based on morphological features. Apart from the deepest position of the Danube valley south of Budapest and the Solt Plain, this extension and related to it subsidence can also be deduced from the microrelief. The surface of the Solt Plain dips gently towards from the Danube valley to its eastern margin having its own drainage network. This network exhibit swampy, deeply located, gentle depressions desiccated by canals. The eastern margin of the plain is partly made up of extensional escarpments facing to southwest, and of arched, approximately $\mathrm{N}-\mathrm{S}$ striking escarpments passing between the latter ones. This morphology and hydrography represent the superficial

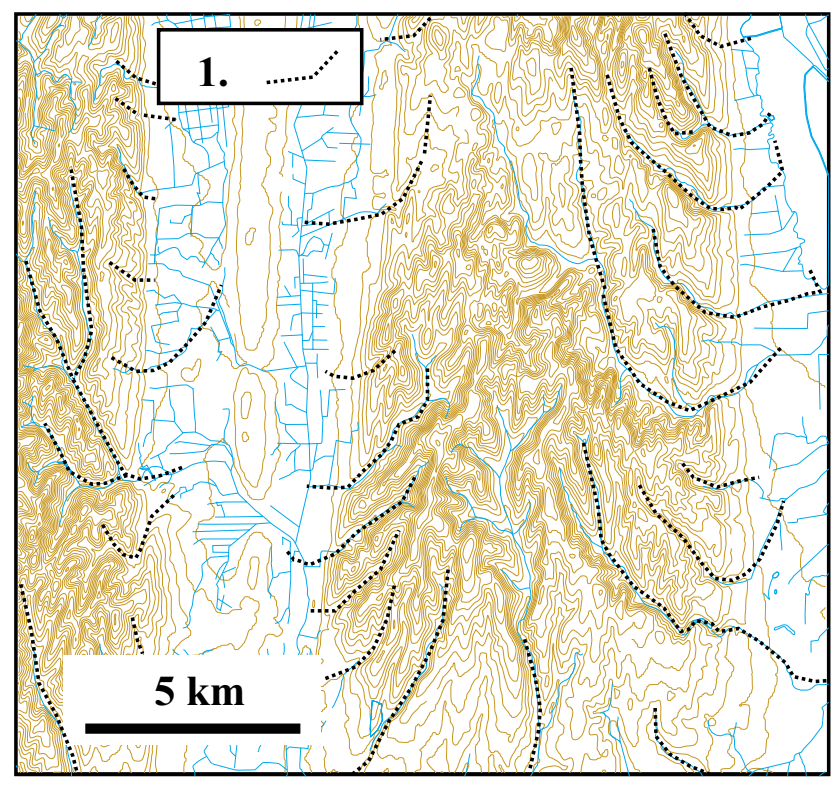

Fig. 8. Relief map of the valley- and drainage reversal on the Zalaapáti Range (ZR). 1: Main valley reversals.

pattern of listric normal faults hereby also called as scarps. Several extensional sub-depressions can be recognised in the Solt Plain based on morphology criteria that were formed as a result of NE-SW extension.

The valley- and drainage reversal is a characteristic feature of the Pannonian sedimentary series covered by Quaternary loess. Ridges in Somogy and Zala Counties south and west of Lake Balaton, respectively are made up of Pannonian deposits and are covered by a thin Pleistocene blanket. Drainage networks are basically fit in the southward oriented, so-called Külső-Somogy (KS) network, but it makes a half-turn northward in the margin of the ranges (Fig. 8). This anomalous pattern suggests that the Pannonian sediments preserved their original, southward oriented stratification and dip on uplifted ranges. The elongated ranges can be characterised by consequent valley network. The short valley segments of opposite orientation are subsequent valleys truncating the bedding front. The valley and drainage pattern of ridges hence complies with the general dipping direction prevailed after sedimentation in the Pannonian inland lake (Müller and Magyar, 1992).

Valleys switching their orientation can be explained by two models. These are (1) the occurrence of generally opposite stratigraphic conditions or (2) very young, practically recently formed depressions among the ranges as shown by the anomalous drainage network.

Saw-tooth like, zigzagged pattern of valley margins (valleys of river Zala, Kapos, Koppány, Jaba, etc.) can be observed in a number of sites in Southern Transdanubia, especially in areas covered by Pannonian and Quaternary deposits (Fig. 6). Theories concerning their origin - whether tectonic or exogenic - are missing. They have been analysed only in Külsô-Somogy where they were interpreted as the margin of 
tilted blocks or the result of thrust faulting due to compressional stresses. They have two specific features. Their main direction is nearly perpendicular to the terrain units with submeridional morphology and they truncate radial morphological and hydrographic structures or at least they displace them laterally.

Hypothesis of their formation is explained in Fig. 7. In compliance with theoretic considerations (Tari, 1991), one component of the saw-teeth geometry is represented by relatively small antithetic lateral displacements, nearly at a right angle to zone of the principal lateral displacement. The other one is characterised by fault planes that are originally parallel to the main structural directions or turning gently. Along these fault planes or headwalls, two processes take place that are induced by block rotation. On one hand, the antithetic lateral displacement thrusts the margin of specific en echelon blocks partly over other blocks resulting in the formation of small, closed extensional basins. On the other hand, the headwall of rotated, uplifted and dissected blocks together form tectonic valleys that are oriented along the strike of the principal lateral displacement zone.

The uplifted areas and zigzagged morphology are mainly accompanied by gravitational types of recent sedimentation: intense erosion and landslides are the key factors of surface evolution. The extensional, triangular depressions become the locus of lacustrine, paludal and fluvial sedimentation. Along the margin of uplifted blocks rapid sedimentation takes place resulting in the formation of alluvial fans.

Another result is that the uplifting Pannonian formations become exposed along the steep flanks of asymmetric valleys.

The arched, truncated ridge- and valley system can be observed first of all in the eastern termination of the Alps and in the central part of Southern Transdanubia. Their characteristic feature is the simultaneous occurrence of a lobe-like, arched, asymmetric valley network and ridge crests parallel to it (Fig. 5). An array of repeated valleys and ridges of similar morphology truncate their strike at an acute angle. This specific anomaly is clearly visible on terrain models and space images and can be explained by the following theory.

Due to the effect of horizontal shortening an asymmetric warping occurs in the Pannonian and Pliocene sediments with fold axes striking approximately E-W creating asymmetric slopes on the surface. Thrust faults occur near the folded areas where they propagate to the surface.

Due to continuous compression, the formation of folds cannot be attributed to a specific, short period of tectonic episode. Several population of structures can be identified. This is manifested by the fact that folding is occasionally combined with thrust faulting that are themselves deformed by younger folds. This phenomenon is quite common in fold belts (e.g. Leith and Alvarez, 1985). These morphological features occur in thick Pannonian formations in the western half of the Pannonian basin at the eastern termination of the Alps. This suggests ongoing compression after Miocene times.
This feature can be observed in a number of sites between the Mura and Vienna basins (MB and VB). Arched antiforms with a size of several kilometres along strike suggest northern vergence. Morphological forms crossing each other suggest northeastward migration, where they gradually become younger in the same direction (Jámbor et al., 1993).

\subsection{Investigation of Southern Transdanubia}

Below we investigate the applicability of the above model to the case of the Kapos line (Némedi-Varga, 1977) between lake Balaton and the Mecsek Range. Figure 9 shows the generalized 1:50000 contour line map of the central and western part of Southern Transdanubia. The strongly uplifted position and dissected morphology of the western part of the Mecsek Range - Zselic (ZS) - and Southern Zalaapáti Range (ZAR_S) is clearly visible. Active erosion and mass movements can be well observed, together with paludal sediments and peats in the Kapos valley (Dömsödi, 1977). These intense exogenous processes on the surface of loesses indicate young uplift and subsidence dated as Upper Pleistocene to recent times. It is proposed here, however, that these features are accessories of a larger scale E-W trending strike-slip fault along the Kapos line. The map shows that morphological edges, as well as boundaries of geological formations (see Fig. 2) of the uplifted blocks contact each other along extremely sharp, nearly N-S-striking lines. Upper Pleistocene loesses blanketing Pannonian outcrops, with southward oriented drainage- and valley network prevail in Külső-Somogy (KS), Marcali Range (MrR), Zalapáti Range (ZAR) and Zala Hills (ZH). Pannonian deposits are missing in the deeper regions that are covered mainly by aeolian sands. The drainage network switches quite to the opposite while the watershed shifts to the south, in the prolongation of Kapos line. It results in the complete turn of streams in the periphery of the hilly ranges. On the contrary, the western continuation of Kapos line is far less traceable, the nearly straight boundaries of geographic and geological units are quite disturbed (Fig. 9).

Evidences and observations are as follow:

- South of the Kapos valley, the prolongation of the western boundary of Külsô-Somogy (KS) as a major geomorphological feature is displaced to the west by several kilometres (western termination of Zselic - ZS). Geographic, morphological and geological conditions remain the same in the two blocks, only the drainage network and catchment area switches to the opposite.

- The south end of the Marcali Range, then an anonymous, gentle elevation in the central part of BelsóSomogy (BS), as well as the eastern periphery of Zalaapáti Range (ZAR) deflect to the west.

- The two morphological edges of the Zalaapáti Range (ZAR) parallel or diverging slightly to the south splay at Nagykanizsa (Nk.) along a zigzagged feature over the west prolongation of the Kapos line. The southern part of the range (ZAR_S) is uplifted, forming a 


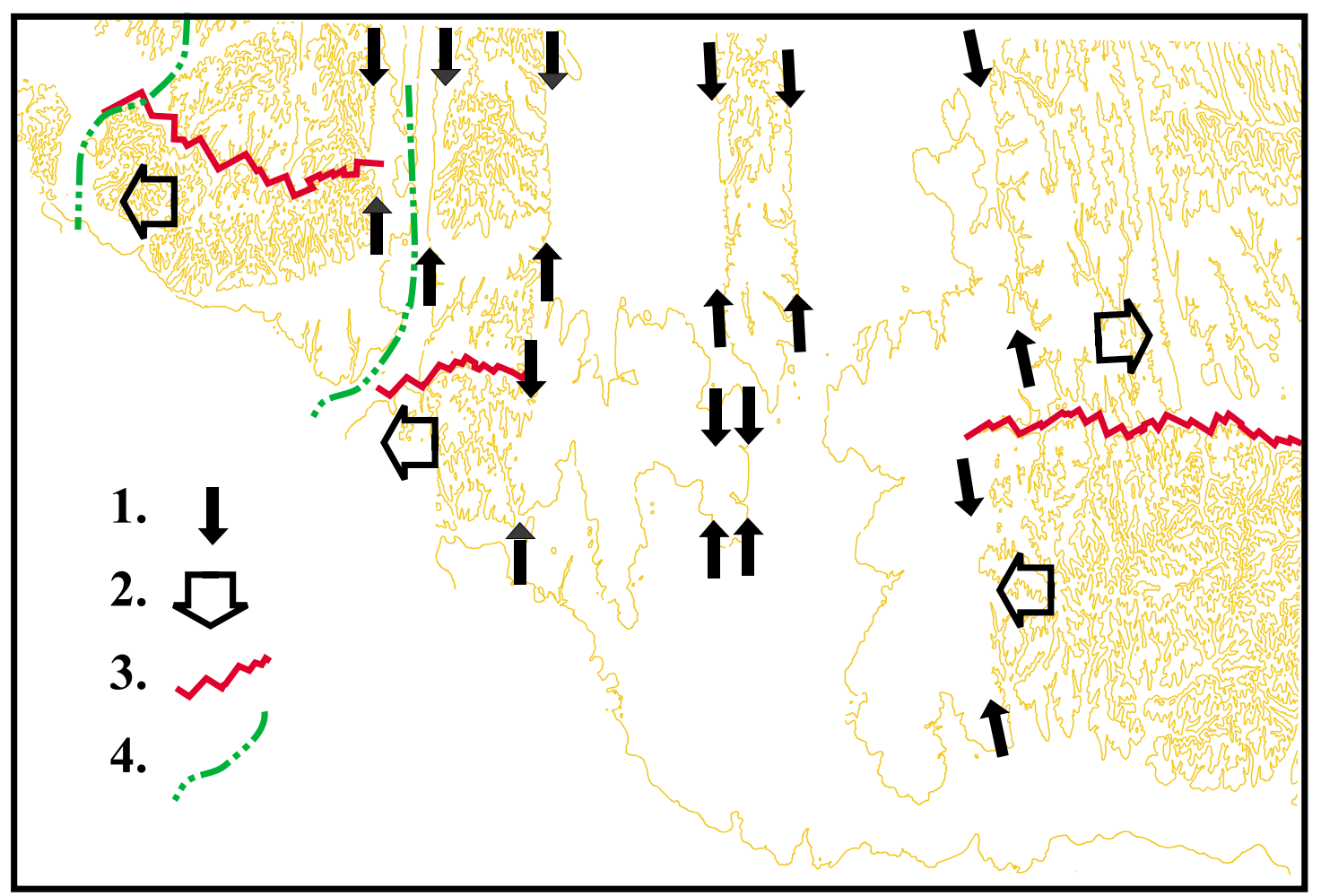

Fig. 9. Relief map of western and central part of the South Transdanubia, showing the westward shifts of the radial pattern south of the Kapos line. Interval of contour lines $50 \mathrm{~m}$. 1: Elements of the radial pattern in morphology, 2: Relative motion directions of neotectonic segments, 3: Elements of the saw-tooth/zigzagged pattern, 4: Shifted river valleys.

nearly isometric shape with radial drainage and valley network and with a local maximum elevation (Zápolca, $248 \mathrm{~m}$ ). The uplifted range offsets the exactly straight Principális valley (PV) to the west.

Application of the theoretical model of shear zones (Fig. 7.) suggests the presence of a dextral strike-slip fault along the Kapos line during Late Quaternary times.

At the eastern prolongation of the Kapos line from Dombóvár (Dv.) to the Sárvíz valley (SV), the morphological features are quite similar to the arched, truncated ridge- and valley systems typical for the eastern margin of the Alps. The asymmetric relief of both Pári Hill (PH) and Tolna Hegyhát Hills (THH) dipping gently to the southeast can be associated with the slight contraction observed in the Pannonian strata. The block of the Pári Hill truncates sharply the saw-toothlike Koppány valley. At the same time, the Kapos valley cuts the Pari Hill to the SE. This segment of the Kapos valley can be regarded as a pre-formed NW edge of a younger compressional structure that uplifted the asymmetrically elevated Tolna Hegyhát Hills.

Most recent data available from Tolna Hegyhát Hills do not provide clues to solve the compression versus extension problem of the area. The boreholes near Diósberény ( $\mathrm{Db}$.) suggest the presence of a normal fault separating Pannonian rocks located at different altitude in the Tolna Hegyhát Hills and Külsô-Somogy (Koloszár and Marsi, 1997). At the same time, hydrogeological modelling (Tóth et al., 1997) and correlation of well-log data (Müller et al., 1997) suggest gentle folding of the sediments. The elevated position of the Lower Pleistocene Tengelic Formation drilled in the Diósberény well can rather be attributed to the local, subsequent uplift of the area.

The eastern prolongation of the Kapos valley crosses the Sárvíz valley. The most spectacular morphological and hydrographic anomalies of Transdanubia are the Mór trough and the Sárvíz valley. They both transect the whole Transdanubian Range. In the south the trough deviates then to the SW and flanks the southern part of Mezofföld (MF_S). This morphological situation is interpreted as an elevated area that belongs also to the dextral strike-slip fault zone along the Kapos valley. It reaches its highest elevation at Sík Hill (SH). The ENE-WSW striking watershed passing through this block separates two parallel valley networks of completely opposite orientation, fitting in the previously described radial pattern. Concerning its role in the geomorphological pattern and valley network, this uplift is quite similar to the southern part of Zalaapáti Range.

The turn of theDanube river near Paks coincides with the strike of the post-Pannonian fault zone observed near the town of Paks (Paks line) (Dudko, 1997). The eastern continuation of the Kapos line east of Paks (P.) is rather uncertain as this shear zone has no visible morphological appearance in the youngest Quaternary series of the Great Hungarian Plain. 


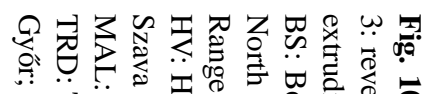

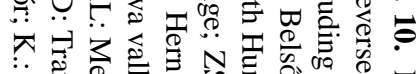

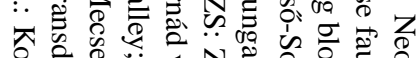
焉记 言它. :

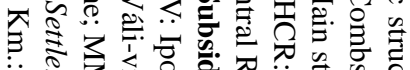

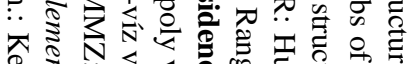

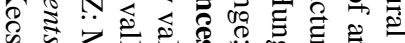

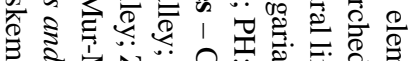
\%

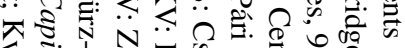

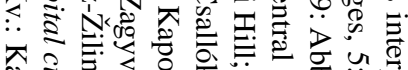
중 ठ

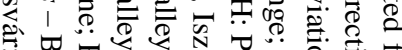

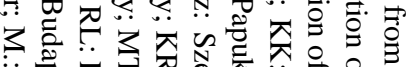

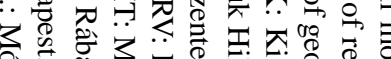

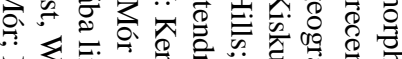

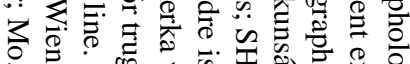

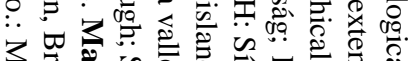

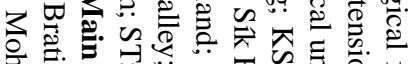

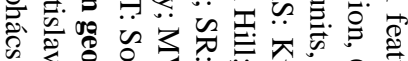

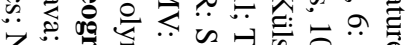
Z

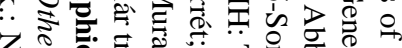
范

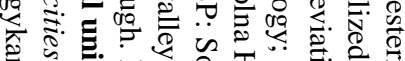

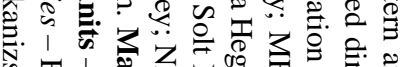

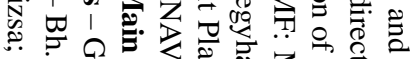
:

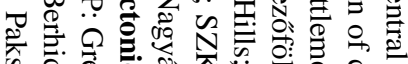

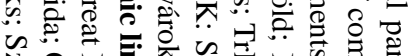

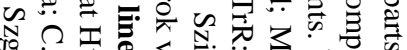

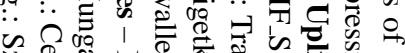

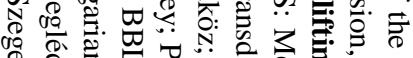

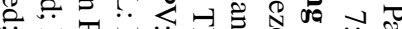

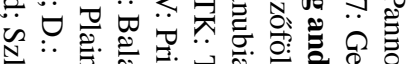

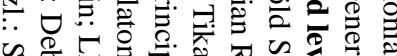

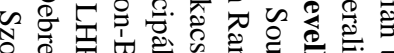

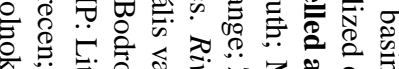

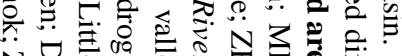

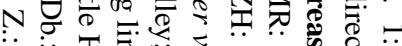

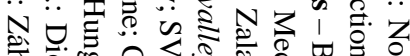

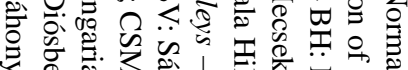

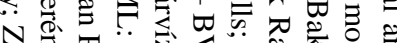

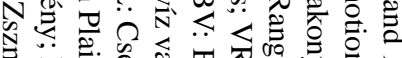

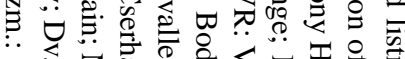

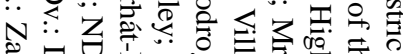

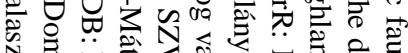

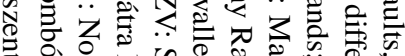

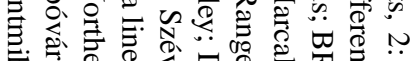

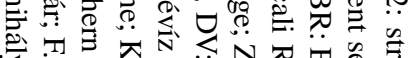

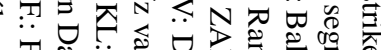

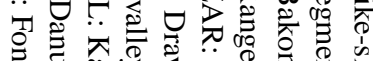

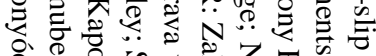

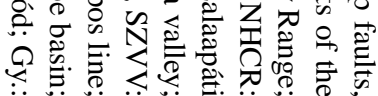

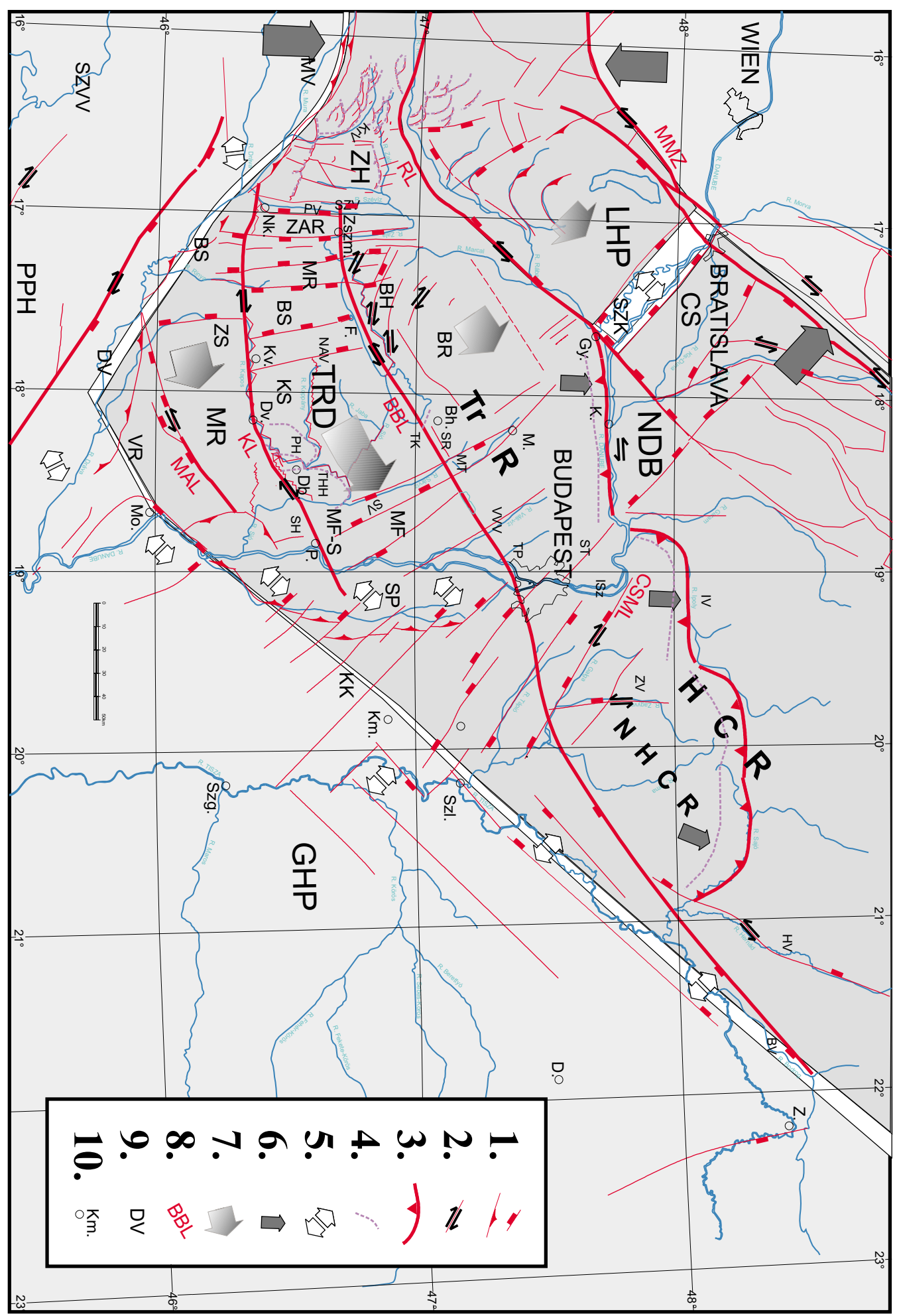




\subsection{On the possible neotectonic origin of the morphology}

Figure 10 summarises the neotectonic fault pattern determined by the analysis of the geomorphology and/or genetic types of Quaternary deposits in the western half of the Pannonian basin system.

In the Eastern Alps and in the western part of the Transdanubia, the maximum horizontal stress axis is aligned to $\mathrm{N}-\mathrm{S}$ direction, that trigs the ENE-NE directed escapeing of a tectonic block that is made up by the North-Pannonian Unit (NPU) and the Mecsek-Villány region of the Tisza unit. Motion of the block is along the Mur-Mürz-Žilina line (MMŽ) with sinistral lateral slips. In the south, the block is displaced along a dextral fault system that are the Periadriatic lineament and its branch in the Dráva valley. Besides the general trend of the motion the block is accompanied with a gentle counterclockwise rotation. Thus the Drava valley and the Tisza valley between Szolnok and Záhony (Z.) are extensional areas.

The maximum horizontal stress axes is oriented N-S in the Eastern Alps and in the westernmost part of the Transdanubia, which is assumed to induce strike-slip fault zones inside the escaping block. These are the Rába line (RL), the Balaton-Bodrog line (BBL), the Kapos line (KL) and the so called Mecsekalja line (MAL). The slight differences of the present-day extrusion velocities between the separated segments result in the formation of active uplifts and pull apart depressions in the restraining and releasing bends of strikeslip faults, respectively.

The Rába line sharply separates the subsiding Little Hungarian Plain from the uplifting areas of the Zala hills and Transdanubian Range. The line is a sinistral strike-slip, which near Gyốr divergences for two components. One turns to the east associated with uplift on the southern bank of the Danube river. The principal displacement zone shifts in a releasing stepover to the Mur-Mürz-Žilina line. This phenomenon is reflected first of all in the Quaternary basin of the Little Hungarian Plain. Thick sediments of Quaternary age plunge from its south-western and north-eastern margins to the Szigetköz trough (SZK) between Bratislava and Gyốr (Draskovits et al., 1995; Scharek et al., 1998). The SW-NE extension of the basin causes normal faulting in the north-eastern part of the North Danubian basin (Kovač et al., 2001), and normal and listric faulting prevail in the southwest. Listric faults probably control the left side tributaries of the Rába river (Répce, Gyöngyös, Sorok etc. rivers). The southern border of the segment coincides with the main geomorphological structure drawing out the south edge of the Transdanubian Range.

The morphology of the northern shore of Lake Balaton is controlled by two components of the presented zigzagged pattern. One of them has a NE-SW, while the other has a W-E direction. The NE-SW direction is related to the morphology of the range and is parallel to the main strike of the ranges. The other direction is associated with strike-slip faults and with left-lateral displacements. The Quaternary movements take place along the reactivated, nearly W-E striking dextral
Miocene faults. In a similar way to the model presented in Fig. 7, these faults are accompanied with a sinistral principal displacement zone along the lake (see Fig. 10). This neotectonically important zone is named on the map as BalatonBodrog Line (BBL). Dextral strike-slips of segments toward the sinistral cutting fault zone formed a series of separated, extensional depressions. These depressions tectonically preformed the initial sub-basins at the starting phase of Lake Balaton's evolution The main, sinistral transversal fault runs undoubtedly under Lake Balaton that prevents its tracing by means of geomorphology. Morphological features that are traceable even on the Upper Pleistocene loesses suggest that the formation of the Balaton basin took place during the Würm or later. Consequently, considering the pre-forming effect of neotectonic processes, the evolution of Lake Balaton may have started only some tens of thousands of years ago. This assumption well corresponds to the data obtained from wells penetrating the bottom sediments of Lake Balaton. These wells indicate the lack of Pliocene and Pleistocene lacustrine sediments between the Pannonian (Miocene) and Holocene lake-bottom sediments (Csernyi and Nagy-Bodor, 2000).

Its presence is indicated through prevailing depressions in morphology along its western and eastern prolongation (see Fig. 10). To the west it is proven by the peat-bearing regions of the Szévíz valley, by the low-lying, swampy areas of Kis-Balaton, and by the bending of the ridge of the Zalaapáti Range (ZAR). To east similar depressions are the Tikacs (TK), the Sárrét (SR), Lake Velence and the swampy, central part of Váli-víz as well. The zone reaches the Danube river at the southern edge of the Tétény Plateau (TP ). To the northeast this young shear zone of sinistral character follows the direction of the main structural units in Hungary. A few related conjugate faults run towards the asymmetrical Zagyva- and Hernád valleys. Then it runs along the axis of the Middle-Tisza and Bodrog valleys forming a sharp dividing line between the regionally uplifted Northern Hungarian Range with its foreland areas and the subsiding Great Hungarian Plain.

\section{Conclusions}

In summary we can make the following conclusions:

- In the eastern termination of the Alps explicit NNESSW compression is effecting the Pannonian (Upper Miocene) strata of the Pannonian basin system. Several generations of E-W striking folds were formed that decisively determines the surface morphology in this area. The eastern termination of this region is between the town of Kôszeg (Ksz) and the Kerka valley (KV) with a sharp N-S boundary.

- Further to the east from the above boundary between the Rába line and Drava valley, to the NE from Danube bend towards the line of Kecskemét (Km.) and the 
Cserhát-Mátra line (CSML) a different morphology pattern prevails. It is characterised by a radial, fan-shaped fault system, which is well reflected in the predominant morphological picture. Their kinematics show both extension and right-lateral strike-slip movements. They were formed as a result of the northeastward motion and small degree counterclockvise rotation of the NPUMecsek block taking place from the end of Pannonian (Late Miocene) time through present times. This is considered as an extrusion due to the strong N-S compression. The phenomenon is the present-day continuation of the escape of the Bakony-Drauzug unit (Transdanubian Range - TrR) as proposed by Kázmér and Kovács (1985) for Paleogene times. The radial fault system traverses the pre-Pannonian ranges only occasionally. However, they play a major role in formation and evolution of the relief and drainage pattern including the whole course of the Danube river between the towns of Győr (Gy.) and Mohács (Mo.).

- The extrusion of the NPU-Mecsek block exerts strong push on the inner side of the Carpathian arch, the southern side of Ipoly valley (IV) and along the uplifted belt of the North-Hungarian Central Range (NHCR). This block cannot, however, be regarded as a uniformly moving unit. Strike-slip faulting occur in the margins of the inner segments that move at different speed relative to the general northeastward bulk speed. These fault zones are along the strike of main structural trends of the Pannonian basin, i.e. they are nearly perpendicular to the radial fault pattern. According to the general direction of the drift, right and left lateral displacaments occur in the S, SE margin and N periphery of the moving segments, respectively.

- The so-called Hungarian Central Range between the Rába river and the Balaton-Bodrog line also the Mecsek Range (MR) between the Kapos- and Mecsekalja lines, are characterised by slower movement, than the area between the Balaton-Bodrog and the Kapos lines.

As the final conclusion of this paper it is pointed out that active neotectonic processes play a key role in shaping the recent landscape. Exogenic processes are restricted to erosion of the margin and surface of neotectonic blocks that are dislocated relative to one another. The magnitude of these processes cannot, however, compete with the effect of endogenic actions. Moreover, the margins of the specific neotectonic blocks fit well to the boundaries of the classic geographic units in the Pannonian basin. Though further investigations are needed undoubtedly, it follows from the Quaternary landscape development that the present-day tectonic evolution of the Central Transdanubia continues the extrusion process of the Mio-Pliocene period (Fodor, 1995; Horváth and Cloetingh, 1996; Bada, 1999; Bada et al., 1999; Gerner et al., 1999).

\section{References}

Ádám, L., Marosi, S., and Szilárd, J. (Eds.): A Dunántúli-dombság (Dél-Dunántúl) (Transdanubian Hilly Range, South Transdanubia). Magyarország tájföldrajza (Descriptive geography of Hungary) 4 (in Hungarian), Akadémiai Kiadó, 95-97, 1981.

Bada, G., Horváth, F., Gerner, P., and Fejes, I.: Review of the present-day geodynamics of the Pannonian basin: progress and problems, Geodynamics, 27, 501-527, 1999.

Balla, Z., Schweitzer, F., Szabó, Z., and Szeidovitz, Gy.: Magyarország földrengésveszélyes övei (Zones of earthquake hazard in Hungary). Manuscript (in Hungarian). MÁFI Project Archive of Dept. of Tectonics, 1993.

Balla, Z.: Van-e bizonyíték negyedidôszaki tektonizmusra Paks környékén? (Is there any proof for Quaternary tectonism in the Paks area?) Földtani Közlöny (in Hungarian), 129, 1, 97-107, 1999.

Brezsnyánszky, K. and Síkhegyi, F.: Neotectonic interpretation of Hungarian lineaments in the light of satellite imagery, J. of Geodynamics, 8, 193-203, 1987.

Brown, R. D. and Kockelman, W. J.: Geologic Principles for Prudent Land Use. USGS Professional Paper, 946, 41-89, 1983.

Cholnoky, J.: A Zala felső völgyének fejlődése (Development of the upper part of the Zala River), in: Results of the scientific investigations of Lake Balaton (in Hungarian), Vol. I., Part II, p. 118, 1918.

Csernyi, T. and Nagy-Bodor, E.: Limnogeology of Lake Balaton (Hungary), in: Gierlowski, E. H. and Kordesch, K. R. (Eds.): Lake basins through space and time. AAPG Studies in Geology, 46, 605-618, 2000.

Czakó, T.: A törésvonalak és a szénhidrogéntartó szerkezetek feltárása a távérzékelés módszerével (Exploration of fracture lines and hydrocarbon-bearing structures by remote sensing method). MTA X. osztályának Közleményei 13/1, (in Hungarian), 53-69, 1980.

Dank, V.: A Dunántúli-dombság szénhidrogén perspektívái (Perspectives of hydrocarbons of the Transdanubian Hilly area). Földrajzi Közlemények XVII. (XCIII.) (in Hungarian), 1-3, 163-170, 1979.

Dömsödi, J.: Lápi eredetû szervesanyag-tartalékaink mezôgazdasági hasznosítása (Agricultural utilisation of organic matter of paludal origin). Mezőgazdasági Kiadó (in Hungarian), 51-52, 57-62, 1977.

Draskovits, P., Dudás, J., Hobot, J., and Tkáčová, H.: Thickness of the Quaternary sediments. 1:500 000. Danube Region Environmental Geology Programme. Geol. Inst. of Hungary, 1998.

Dudko, A.: Neogene tectonics of the Mezóföld. Annual Report of the Geol. Inst. of Hungary, 1996/II, 214-223, 1997.

Fodor, L.: From transpression to transtension: Oligocene-Miocene structural evolution of the Vienna basin and the East AlpineWestern Carpathian junction. Tectonophysics, 242, 1-32, 1995.

Franyó, F.: Magyarázó Magyarország 200000-es földtani térképsorozatához (Explanatory text to the geological map series of Hungary). L-33-XI, Zalaegerszeg. (in Hungarian), 91-92, 1976.

Franyó, F.: Quaternary thickness map of Hungary. 1:200 000. Partly corrected with new data of Geol. Inst. of Hungary. Manuscript, Project of the unified geological map systems, 1992.

Földváry, Sz.-né, Miskolczi, L., and Rádai, Ö.: Törésvonalak vizsgálata geodéziai mikrohálózatokkal (Surveying fault lines by geodesic micronets). Földtani Közlöny (in Hungarian), 116, 6574, 1986. 
Gerner, P.: Recens kőzetfeszültség a Dunántúlon (Recent stress field in Transdanubia, Western Hungary). Földtani Közlöny (in Hungarian with English abstract), 122, 1, 89-105, 1992.

Gerner, P.: Dél-dunántúli neotektonikai modellek a magyar földtani szakirodalom alapján (Neotectonic models of SW-Hungary based on the Hungarian geological literature; a review). Földtani Közlöny (in Hungarian with English abstract), 124, 3, 381-402, 1994.

Gerner, P., Bada, G., Dövényi, P., Müller, B., Oncesu, M. C., Cloetingh, S. A.P.L., and Horváth, F.: Recent tectonic stress and crustal deformation in and around the Pannonian Basin: data and models, in: Durand, B., Jolivet, L., Horváth, F., and Seranne, M. (Eds.): The Mediterranean Basins: Tertiary Extension within the Alpine Orogen. Geol. Soc. London, Special Publications, 156, 269-294, 1999.

Halouzka, R., Schäffer, G., and Kaiser, M. (Eds): Neotectonic map, Danube Region. 1:200 000. Danube Region Environmental Geology Programme. Geol. Inst. of Hungary, 1998.

Horváth, F. and Cloetingh, S. A. P. L.: Stress-induced late-stage subidence anomalies in the Pannonian basin. Tectonophysics, 266, 287-300, 1996.

Jamičič, D.: The role of sinistral strike-slip faults in the formation of the structural fabric of the Slavonian Mts. (Eastern Croatia). Geol. Croat., 48/2, 155-160, 1995.

Jámbor Á, Bihari, D, Chikán, G., Franyó, F., Kaiser, M., Radócz, Gy., and Síkhegyi, F.: Magyarország pleisztocénben aktív törései (Active Pleistocene faults in Hungary). 1:500 000. Map and exploratory text. Manuscript (in Hungarian). MÁFI Project Archive of Dept. of Tectonics, 1993.

Joó, I., Arabadžijski, D., Mladenovski, M. M. et al. (Eds.): Map of recent vertical movements in the Carpatho-Balkan Region. 1:1 000 000, FÖMI-Cartographia Co., 1985.

Joó, I.: Recent vertical surface movements in the Carpathian basin. Tectonophysics, 202, 120-134, 1992.

Kázmér, M. and Kovács, S.: Permian-Paleogene paleogeography along the eastern part of the Insbric-Periadriatic lineament system: evidence for continental escape of the Bakony-Drauzug unit. Acta Geologica Hungarica, 28, 71-84, 1985.

Koloszár, L. and Marsi, I.: Stratigraphy of the Neogene and Quaternary sequences of the Tolna Hegyhát Hills. Annual Report of the Geol. Inst. of Hungary, 1996/II, 173-184, 1997.

Kovač, M., Hók, J., and Šujan, M.: Pliocene-Quaternary rifting and the present stress field of the Western Carpathians. Extract from the symposium on the Post-Pannonian tectonics of the Carpathian basin, p 1, 2001.

Körössy, L.: Magyarország medenceterületeinek összehasonlító földtani szerkezete (Compeared geological structures of the basins in Hungary). Földtani Közlöny (in Hungarian), 93, 2, 153-172, 1963.

Leith, W. and Alwarez, W.: Structure of the Vaksh fold-and-thrust belt, Tadjik SSR: Geologic mapping on a Landsat image base. Geol. Society of America Bulletin, 96, 875-885, 1985.

Lóczy, L., sen.: A pannoniai-pontusi rétegek vastagsága és tektonikája (Thickness and tectonics of the Pontian strata), in: Results of the scientific investigations of Lake Balaton (in Hungarian). Vol. I., 402-403, 1913.

Lóczy, L. jr.: A Magyar medencerendszer geomorfológiája, különös tekintettel a petroleum-kutatásra (Geomorphology of the Hungarian basins with particular respect for the petroleum exploration), Földrajzi Közlemények (in Hungarian), 67/4, p. 384, 1939.

Maglay, J., Halouzka, R., Baňacky, V., Pristaš, J., and Jančoko, J.:
Neotectonic map of Slovakia. 1:500 000, Geol. Surv. of Slovak Rep., Bratislava, 1999.

Marosi, S. and Schweitzer, F.: Geomorfológiai vizsgálatok Paks környékén (Geomorphological investigations at the neighbourgh of Paks), in: A Paksi Atomerőmú földrengésbiztonsága (Seismic safety of the Paks nuclear power plant) (in Hungarian), Akadémiai Kiadó, Budapest, 153-175, 1997.

Moldvay, L.: A $450 \mathrm{~km}$ long rupture zone between the CzechMoravian Hills, Southern Transdanubia and Kiskunság. Acta Geod. Geoph. Mont. Hung., 24, (3-4), 449-452, 1989.

Müller, P. and Magyar, I.: A Prosodacnymiák rétegtani jelentősége a Kötcse környéki pannóniai s.l. képződményekben (Stratigraphic importance of Prosodacnymidae in the Pannonian s.1. formations in the neighbourgh of Kötcse). Földtani Közlöny (in Hungarian), 122, 1, 1-38, 1992.

Müller, P., Tóth-Makk, Á., and Juhász, E.: Correlation of Neogene beds by well-log curves in the Tolna Hegyhát and Mórágy areas. Annual Report of the Geol. Inst. of Hungary 1996/II, 203-208, 1997.

Némedi Varga, Z.: A Kapos-vonal (The Kapos Line). Földtani Közlöny (in Hungarian), 107, 3-4, 313-328, 1977.

Némedi Varga, Z.: A Mecsek hegység szerkezetalakulása az alpi hegységképződési ciklusban (Structural development of the Mecsek Mts. in the Alpine orogene cycle). Annual Report of the Geol. Inst. of Hungary 1981 (in Hungarian), 467-484, 1983.

Némedi Varga, Z.: A Tengelic 1. sz. szerkezet-és vízkutató-, valamint a Tengelic 2. sz. alapfúrás összehasonlító földtani és szerkezeti vizsgálata (Geological and structural investigation of boreholes Tengelic 1 and 2). Annual Report of the Geol. Inst. of Hungary 1984, 103-114, 1986.

Pécsi, M.: Various explanations to the origin of the meridional valleys and ridges in the Zala hills. Földrajzi Közlemények (in Hungarian with English summary), XXXIV. (CX.), 1-2, 3-11, 1986.

Ratschbacher, L., Frisch, W., Linzer, H.-G., and Merle, O.: Lateral extrusion in the Eastern Alps, part II: structural analysis. Tectonics, 10, 257-271, 1991.

Rádai, Ö.: Subsurface water environment and the reconnaissance of it by aerospace methods in Hungary. Proceeding of the ISPIUFRO Symposium in Freyburg, 1978.

Rónai, A.: A Magyarországi kvarter képződmények kifejlődése és szerkezeti helyzete (Facies and structural position of the Quarternary sediments in Hungary). Földtani Közlöny (in Hungarian), 116, 1, p. 34, 1986.

Rumpler, J. and Horváth, F.: Some representative seismic reflection lines and structural interpretation from the Pannonian basin, in: Royden, L. H. and Horváth, F. (Eds.): The Pannonian basin - a study in basin evolution. AAPG Mem., 45, 153-169, 1988.

Sabins, jr., F. F.: Remote sensing. Principles and interpretation. W. H. Freeman and Co. San Francisco, p. 426, 363-374, 1978.

Scharek, P., Hermann, P., Kaiser, M., Pristaš, J., and Tkáčová, H.: : Genetic types and thickness of Quaternary sediments. 1:200 000. Danube Region Environmental Geology Programme. Geol. Inst. of Hungary, 1999.

Síkhegyi, F.: Kozmikus felvételek szerkezeti értelmezése. (Structural interpretation of satellite images), in: Gyakorlati szerkezetföldtani továbbképző, MFT Budapest (in Hungarian), 129-144, 1985.

Síkhegyi, F., Angyal, J., Kalafut, M., Rakonczai, K., and Szurkos, G.: Térkép és magyarázó Magyarország 500000-es lineamentum térképéhez. (Map and explanatory text to the lineament map of Hungary). Scientific and Research Found of Hungary (OTKA) Report, Archive of Geological Survey of Hungary. T. 16873. 
Manuscript (in Hungarian), 1992.

Síkhegyi, F., Angyal, J., Marsi, I., Szurkos, G., and Tamás, G.: Magyarország jelenkorban emelkedő és süllyedő területeinek elkülönítése (Determination of the recent subsiding and uplifting areas in Hungary). Integrated Basin Studies, Open report (in Hungarian, with abstract in English). ELTE, Dept. of Geophysics, 1996.

Schweitzer, F.: Domborzatformálódás a Pannóniai-medence belsejében a fiatal újkorban és a negyedidőszak határán. Relief formation in the Pannonian basin in the Late Cenozoic and at the boundary of the Quaternary age. Acad. D. theses (in Hungarian), 1993.

Tari, G.: Multiple Miocene block rotation in the Bakony Mountains, Transdanubian Central Range, Hungary. Tectonophysics, 199, 93-108, 1991.

Tóth, Gy., Gondár-Sőregi, K., Rotár-Szalkai, Á., Horváth, I., Nádor, A., and Szőcs, T.: Hydrogeological conditions in the Udvari and Diósberény sites and their surroundings. Annual Report of the Geol. Inst. Of Hungary 1996/II, 232-246, 1997. 